\title{
CORRESPONDENCE
}

\section{CRYPTOSPORIDIOSIS AMONG PATIENTS WITH THE ACQUIRED IMMUNODEFICIENCY SYNDROME IN MARACAIBO, VENEZUELA.}

Cryptosporidium is a coccidian parasite found in the intestinal and respiratory epithelia of a wide varicty of vertebrate hosts. The first cases of human cryptosporidiosis were reported in $1976^{14,16}$. Since 1982 there has been a dramatic increase of human cases, most of them with acquired immunodeficiency syndrome (AIDS). Cryptosporidium practically unknown before AIDS outbreak, has become one of the most common intestinal protozoa. Prevalence rates obtained from large-scale surveys of selected populations range from $0.6 \%$ $20 \%$ for developed countries and $4 \%-20 \%$ for developing countries ${ }^{8,1220}$. Nowadays, this coccidio is recognized as a cause of self-limited diarrheal illness in immunocompetent persons and of severe, sometimes life-threatening and protracted diarrhoea, in immunosuppressed persons, particularly those with AIDS $1,2,9,14-16,18,22$.

In patients with AIDS, prevalence rates of Cryptosporidium of $3 \%-4 \%$ have been estimated in the United States ${ }^{2}$. In symptomatic patients the frequency is higher: $28 \%(5 \text { of } 18)^{12}$ and $23.3 \%(7 \text { of } 30)^{24}$. In Brazil, Africa and Haiti infection rates of $12.1 \%-17 \%^{4,6}, 30 \%-50 \%^{3,5,19}$ and $46 \%{ }^{5,19}$ respectively, have been reported. In Salamanca (Spain), a percentage of $12.5 \%$ was found in patients with antibodies against the human immunodeficiency virus (HIV) ${ }^{11}$.

In Venezuela, there is scarce information about cryptosporidiosis. Infection rates of $10.8 \%$ and $2.5 \%$ - $4 \%$ have been reported in children with acute diarrhea in Caracas and Barquisimeto respectively ${ }^{7,17}$. In Maracaibo, the capital of Zulia State, reports on this parasite are lacking, exception made for a seroepidemiological study of 84 venezuelan children with an enzyme-linked immunosorbent assay. Only 22 children were from Zulia State and 3 of them were from Maracaibo. The percentage of seropositivity for both specific $\operatorname{IgG}$ and $\operatorname{IgM}$ antibodies was $15.5 \%{ }^{23}$. These findings suggest that the infection is endemic in Zulia State.

Here we report a preliminary study designed to evaluate the prevalence and clinical significance of Cryptosporidium in patients with AIDS from Maracaibo.
Ten symptomatic patients referred to our laboratory from the Regional Immunology Unit of Zulia State were studied. All of them were resident in Maracaibo, aged 7 to 35 years. Seven were male and 3 females. All of the patients had mild or severe diarrhea and some had one or more of the following manifestations: abdominal pain, malaise, weight loss, cough with expectoration, lymphadenopathy, candidiasis and herpes.

Three stool specimens were collected from each patient. For the recovery and identification of Cryptosporidium the modified Ziehl-Neelsen carbolfuchsin stain on $10 \%$ formalin preserved stool was used ${ }^{10}$. For the diagnosis of other parasites direct wet mounts and smears stained with iron hematoxylin were examined ${ }^{21}$.

Four patients (40\%) had Cryptosporidium oocysts (Fig.1), associated with Trichuris trichiura and Blastocystis hominis, in one case. Two patients (20\%) had only Giardia lamblia trophozoites. All the cases infected with Cryptosporidium revealed an inflammatory exudate plenty of leukocytes, plasma cell and macrophages. Two of them had Charcot-Leyden crystals.

A multitude of opportunistic infections has been documented in patients with AIDS. Gastrointestinal illness are among the most common and debilitating complication, affecting $50 \%$ to almost $100 \%$ of AIDS patients in developed and developing countries, respectively ${ }^{13}$. Cryptosporidiosis has been recognized as one of the most frequent opportunistic infection in AIDS patients. Therefore, research on the prevalence and clinical significance of this coccidio in our country is necessary.

Although the data of this study are limited, Cryptosporidium appears to be very common in AIDS patients from Maracaibo. The frequency obtained $(40 \%)$ is higher than that observed in the United States and Brazil ${ }^{2,4,6,12,24}$ and similar to the frequencies reported from Africa and Haititi ${ }^{35,19}$.

Multiple concurrent infections are common in AIDS patients. Therefore one cannot unequivo- 
CHACIN-BONILLA, L.; GUANIPA, N.; RALEIGH, X.; CANO, G. \& QUIJADA, L - Cryptosporidiosis among patients with the acquired immunodeficiency syndrome in Maracaibo, Venezuela. Rev. Inst. Med. trop. S. Paulo, 33 (4): 333-335, 1991.

cally assign an etiologic role to Cryptosporidium of the gastrointestinal symptoms of the infected patients, in the absence of bacterial and viral agents. However, the high frequency of the infection in the patients suggest a significant role of this coccidio in the etiology of diarrhea of AIDS patients in Venezuela.

It has been pointed out that the main symptom of cryptosporidiosis is a non-inflamatory diarrhea and leukocytes are rarely seen ${ }^{8}$. In this study an inflamatory exudate with abundant leukocytes was noted in all of the infected patients. This observation may be due to other associated enteropathogens and requires further investigation.
Charcot-Leyden crystals are common in Isosporiasis. We observed plenty of these crystals in two of the cases with Cryptosporidium.

In Venezuela, further investigations are necessary in order to evaluate the prevalence and clinical significance of this coccidio, specially in AIDS patients to be able to manage successfully these patients.

An increase in the diagnosis of Cryptosporidium and other enteric coccidial parasites will likely parallel the increase in AIDS, therefore physicians must be aware of these parasites as causes of chronic diarrhea in these patients.

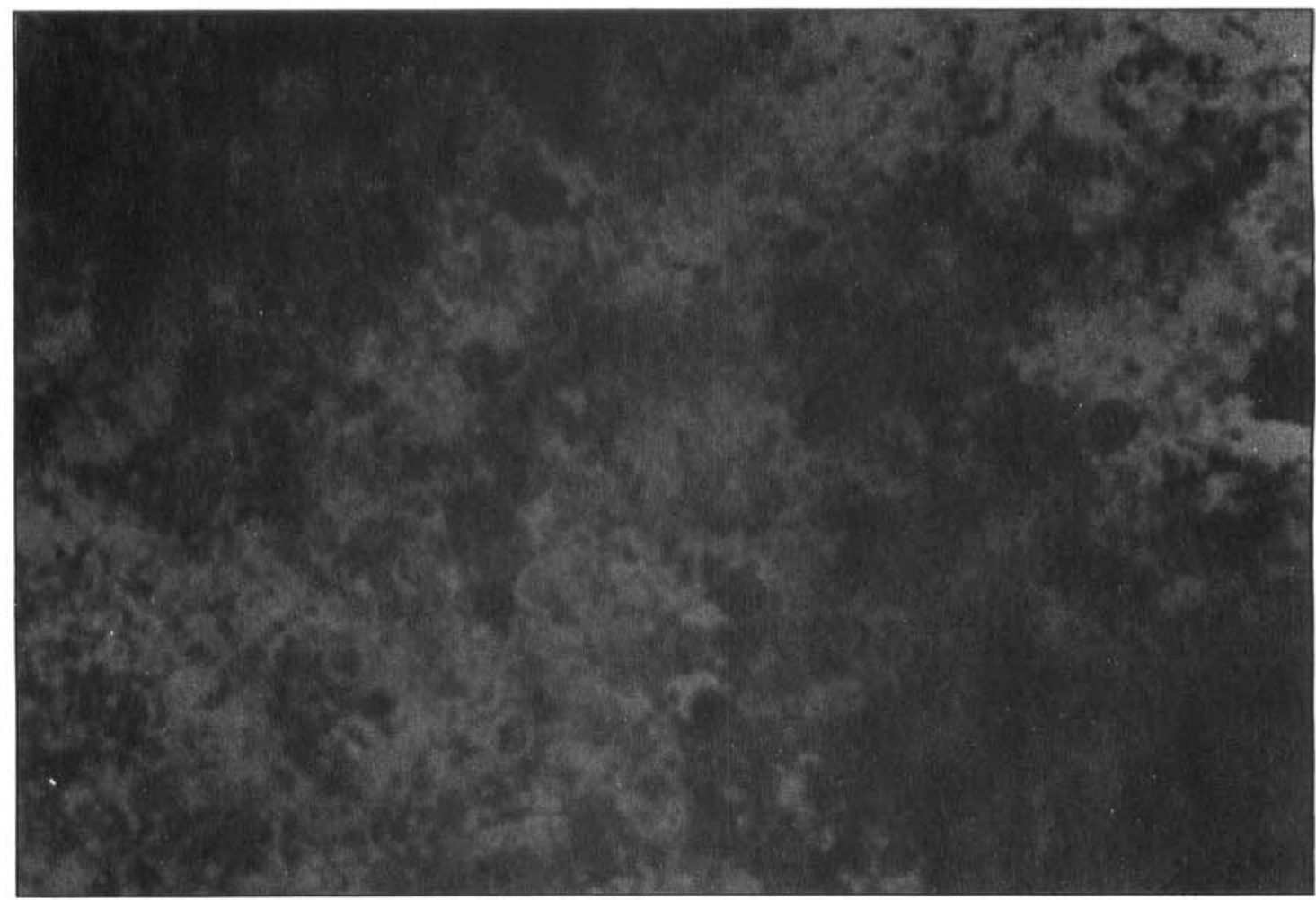

Fig. 1- Cryptosporidium oocysts recovered from stool material and stained by the modified Ziehl-Neelsen carbolfuchsin stain (X 1.000)

\section{ACKNOWLEDGMENTS}

This investigation was supported by Cervecería Modelo from Maracaibo.

\section{REFERENCES}

1. ANGUS, K.W. - Cryptosporidiosis in man, domestic animals and birds. J. roy. Soc. Med., 76: 62-70, 1983.
2. CENTERS FOR DISEASE CONTROL. Cryptosporidiosis: Assessment of chemotherapy of males with acquired immune deficiency syndrome (AIDS). M.M.W.R., 31: 589-592, 1982.

3. COLEBUNDERS, R.; LUSAKUMUNI, K.; NELSON, A.M.; GIGASE, P.; LEBUGUE, I.; VAN MARCK, E.; KAPITA, B.; FRANCIS, H.; SALAUN, J.J.; QUINN, T.C. \& PIOT, P. - Persistent diarthoea in Zairian AIDS patients: an endoscopic and histological study. Gut, 29: 1687-1691, 1988. 
CHACIN-BONILLA, L.; GUANIPA, N.; RALEIGH, X.; CANO, G. \& QUIJADA, L. - Cryptosporidiosis among patients with the acquired immunodeficiency syndrome in Maracaibo, Venezuela. Rev. Inst. Med. trop. S. Paulo, 33 (4): 333-335, 1991.

4. COURA, J.R. - Parasitoses nos portadores de AIDS. J. bras. Med., 53: 42-54, 1987.

5. DEHOVITZ, J.A.; PAPE, J.W.; BONCY, M. \& JOHNSON Jr., W.D. - Clinical manifestations and therapy of Isospora belli infection in patients with the acquired im. munodeficiency syndrome. New Engl. J. Med., 315: 87 90, 1986.

6. DIAS, R.M.D.S.; MANGINI, A.C.S.; TORRES, D.M.A.G.V.; CORREA, M.O.A.; LUPETTI, N.; CORREA, F.M.A. \& CIIEFI, P.P. - Cryptosporidiosis among patients with acquired immunodeficiency syndrome (AIDS) in the country of São Paulo, Brazil. Rev. Inst. Med. trop. S. Paulo, 30: 310-312, 1988.

7. DIAZ, O.F; DE DIAZ, M.C.E. \& QUINTERO, C.H. Cryptosporidiosis en niños con gastroenteritis hospitalizados y tratados ambulatoriamente en Barquisimeto. Gen, 41: 1-6, 1987.

8. FAYER, R. \& UNGAR, B.L.P. - Cryptosporidium spp. and Cryptosporidiosis. Microbiol. Rev., 50: 458-483, 1986.

9. FLETCHER, A.; SLMS, T.A. \& TALBOT, I.C. Cryptosporidial enteritis without general or selective immune deficiency. Brit. med. J., 285: 22-27, 1982.

10. GARCIA, L.S.; BRUCKNER, D.A.; BREWER, T.C. \& SHIMIZU, R.Y. - Techniques for the recovery and identification of Cryptosporidium oocysts from stool specimens. J. clin. Microbiol, 18: 185-190, 1983.

11. GARCIA, R.J.A.; MARTIN, S.A.M.; CANUT, B.A.; GARCIA, L.E.J. \& LUNA, R.G. - Incidence of Cryptosporidium sp in patients treated in a general hospital. Technics for the identification of cocysts in feces. Med. Clin., 93: 164-168, 1989.

12. JANOFF, E.N. \& RELLER, L.B. - Cryptosporidium species, a protean protozoan. J. clin. Microbiol., 25: 967 975, 1987.

13. JANOFF, E.N. \& SMITH, P.D. - Perspectives on gastrointestinal infections in AIDS. Gastroenterol. clin. North. Amer., 17: 451-463, 1988.

14. MEISEL, J.L.; PERERA, D.R.; MELIGRO, C. \& RUBIN, C.E. - Over-whelming watery diarmea associated with Cryptosporidium on an immunosuppressed patient. Gastroenterology, 70: 1156-1160, 1976.

15. NAVIN, T.R. \& JURANEK, D.D. - Cryptosporidiosis:
Clinical epidemiological and parasitological review. Rev. infect. Dis., 6: 313-327, 1984.

16. NIME, F.A.; BUREK, J.D.; PAGE, D.L.; HOLSCHER, M.A. \& YARDLEY, J.H. - Acute enterocolitis in human being infected with the protozoan Cryptosporidium. Gastroenterology, 70: 592-598, 1976.

7.PEREZ-SCHAEL, I.; BOHER, Y.; MATA, L.; PEREZ, M. \& TAPIA, F.J. - Cryptosporidiosis in venezuelan children with acute diarthea. Amer. J. trop. Med, 34: 721-722, 1985.

18. PITLIK, S.D.; FAINSTEIN, V.; GARZA, D.; BOLIVAR, R.; RIOS, A.; HOPFER, R.L. \& MANSELL, P.A. - Human cryplosporidiosis: Spectrum of disease: report of six cases and review of the literature. Arch. intern. Med., 143: 2269-2275, 1983

19. QUINN, T.C.; MANN, J.M.; CURRAN, J.W. \& PIOT, P. - AIDS in Africa: an epidemiologic paradigm. Science, 234: $955-963,1986$.

20. SOAVE, R. \& ARMSTRONG, D. - Cryptosporidium and cryptosporidiosis. Rev. infect. Dis., 8: 1012-1023, 1986.

21. TOMPKINS, V.N. \& MILLER, J.K. - Staining intestinal protozoa with iron-hematoxylin-phosphotungstic acid. Amer. J. clin. Path., 17: 755-757, 1947.

22. TZIPORI, S. - Cryptosporidiosis in animals and humans. Microbiol. Rev., 47: 84-96, 1983.

23. UNGAR, B.L.P.; GILMAN, R.H.; LANATA, C.F. \& PEREZ-SCHAEL, I. - Seroepidemiology of Cryptosporidium infection in two latin American populations. J. infect. Dis., 157: 551-556, 1988.

24. WHITESIDE, M.E.; BARKIN, I.S.; MAY, R.G.; WEISS, S.D.; FISCHL, M.A. \& MacLLEOD, C.L. - Enteric coccidiosis among patients with the acquired immunodeficiency syndrome. Amer. J. trop. Med. Hyg., 33: 1065$1072,1984$.

Instituto de Investigaciones Clínicas Leonor CHACIN-BONILLA Universidad del Zulia Neuro GUANIPA Apartado Postal $1151 \quad$ Xiomara RALEIGH Maracaibo, Venezuela Georgina CANO Luis QUIJADA

Recebido para publicação em 26/04/1991. Accito para publicação em 23/05/1991. 